\title{
Przeszczepienie krwiotwórczych komórek macierzystych w nawrotowej wtórnej limfohistiocytozie hemofagocytarnej
}

\author{
Hematopoietic stem cell transplantation in secondary \\ relapsed hemophagocytic lymphohistiocytosis
}

\begin{abstract}
Bożena Katarzyna Budziszewska ${ }^{1,2}$, Kinga Kos-Zakrzewska ${ }^{1}$, Kazimierz Hałaburda ${ }^{3}$, Barbara Nasiłowska $^{3}$, Monika Prochorec-Sobieszek ${ }^{4}$, Krzysztof Warzocha ${ }^{1}$, Ewa Lech-Marańda1, 2

${ }^{1}$ Klinika Hematologii, Instytut Hematologii i Transfuzjologii, Warszawa

${ }^{2}$ Klinika Hematologii i Transfuzjologii, Centrum Medyczne Kształcenia Podyplomowego, Warszawa

${ }^{3}$ Klinika Transplantacji Komórek Krwiotwórczych, Instytut Hematologii i Transfuzjologii, Warszawa

${ }^{4}$ Pracownia Patomorfologii, Zakład Diagnostyki Hematologicznej, Instytut Hematologii i Transfuzjologii, Warszawa
\end{abstract}

\begin{abstract}
Streszczenie
Limfohistiocytozy hemofagocytarne (HLH) to rzadkie choroby o ciezkim przebiegu klinicznym, obciażone okoto 50-procentowa śmiertelnościa. Wyrózinia sie pierwotna HLH - rodzinna limfohistiocytoze hemofagocytarna, inaczej HLH zwiazana z defektem genetycznym, oraz wtórna HLH towarzyszaca chorobom nowotworowym, autoimmunizacyjnym $i$ infekcjom. Prezentowany przypadek jest przyktadem wtórnej HLH indukowanej najprawdopodobniej zakazeniem bakteryjnym. Niepetny obraz kliniczny i trudności diagnostyczne w ocenie histopatologicznej potwierdzaja, że rozpoznanie HLH jest wyzwaniem dla klinicysty. Objawy HLH sq niespecyficzne i czesto naktadaja sie na objawy infekcji czy chtoniaków. W opisywanym przypadku rozpoznanie HLH $i$ identyfikacja prawdopodobnego czynnika etiologicznego byly opóźnione z powodu podejrzenia chtoniaka T-komórkowego, który ostatecznie wykluczono. Chorego poddano leczeniu, wedtug protokotu Histicyte Society HLH-1994, obejmujacemu podawanie deksametazonu, etopozydu i cyklosporyny A (CsA), po którym uzyskano normalizacje wskaźników laboratoryjnych HLH i ustapienie cytopenii we krwi obwodowej. W leczeniu podtrzymujacym stosowano CsA, co nie zapobiegto jednak kolejnym nawrotom petnoobjawowej HLH. W zwiazku z tym u chorego przeprowadzono allogeniczne przeszczepienie krwiotwórczych komórek macierzystych (allo-HSCT) od dawcy niespokrewnionego. W badaniach kontrolnych $w+100$. dobie po allo-HSCT oraz $w$ kolejnych, powtarzanych co 3 miesiace, stwierdzano petna regeneracje hematopoezy oraz 100\% chimeryzmu dawcy w komórkach jednojadrzastych krwi obwodowej. Obecnie, 20 miesiecy po allo-HSCT, chory pozostaje w ciqgtej remisji choroby, bez objawów niepożadanych zwiazanych z procedurq allo-HSCT $i$ kontynuuje prace zawodowa.
\end{abstract}

Słowa kluczowe: limfohistiocytoza hemofagocytarna, zespół hemofagocytarny, protokół HLH-1994, przeszczepienie allogenicznych krwiotwórczych komórek macierzystych

Hematologia 2016; 7, 4: 327-338

Adres do korespondencji: Bożena Katarzyna Budziszewska, Klinika Hematologii, Instytut Hematologii i Transfuzjologii, ul. Indiry Gandhi 14, 02-776 Warszawa, tel. 2234962 99, faks 22349 63 35, e-mail: budzisze@poczta.onet.pl 


\begin{abstract}
Hemophagocytic lymphohistiocytosis $(H L H)$ is a rare condition having a severe clinical course and $50 \%$ mortality. Two subgroups of HLH may be distinguished: familial HLH or HLH due to genetic defects and secondary HLH linked to neoplasms, autoimmunological diseases and infections. The case presented is of secondary HLH apparently resulting from bacterial infection. Diagnosing HLH is a clinical challenge due to unclear clinical presentation and diagnostic difficulties in histopathogical evaluation. Patients with HLH have non-specific symptoms that may overlap with symptoms of an underlying condition like infections or lymphoma. In the presented case, diagnosis of HLH was delayed due to suspected lymphoma, that was subsequently ruled out. The Histiocyte Society HLH-1994 protocol of treatment was initiated based on dexamethasone, etoposide and cyclosporine A (CsA). A normalization of laboratory markers for HLH was achieved and cytopenia was resolved. Maintenance treatment with CsA was administered, but a recurrence of HLH was noted. The patient was referred to allogeneic hematopoietic stem cells transplantation (allo-HSCT) from the bone marrow of an unrelated donor. The follow up at the +100 day and then subsequently every 3 months after allo-HSCT showed a full hematological recovery and 100\% donor chimerism. At present, 20 months after transplantation, total remission of $H L H$ is noted. The patient does not present any adverse events linked to transplantation and is pursuing his professional career.
\end{abstract}

Key words: hemophagocytic lymphohistiocytosis, hemophagocytic syndrome, HLH-1994 protocol, allogeneic hematopoietic stem cells transplantation

Hematologia 2016; 7, 4: 327-338

\section{Wprowadzenie}

Limfohistiocytozy hemofagocytarne (HLH, hemophagocytic lymphohistiocytosis), określane powszechnie mianem zespołu hemofagocytowego (HS, hemophagocytic syndrome), są grupą chorób układu immunologicznego wywołanych przez zaburzenia funkcji komórek naturalnej cytotoksyczności (NK, natural killers). Zaburzenia te prowadzą do proliferacji i aktywacji limfocytów oraz histiocytów $z$ niekontrolowaną hemofagocytozą i nadprodukcją cytokin. W konsekwencji tych zaburzeń dochodzi do niewydolności wielonarządowej [1].

Wyróżnia się pierwotną i wtórną postać HLH. Postać pierwotna może być rodzinną limfohistiocytozą hemofagocytarą (FLH, familial lymphohistiocytosis), związaną z defektem genetycznym dziedziczonym autosomalnie recesywnie i ujawniającą się w pierwszych latach życia, lub może występować w każdym wieku (late onset $H L H$ ) i wówczas jest $z$ wiązana $z$ występowaniem mutacji genów PRF1, UNC13D, STX11, RAB27A, STXBP2 $[1,2]$. Częstość występowania FLH na świecie nie jest znana; jedynie w Szwecji i Stanach Zjednoczonych określono zapadalność na nią, odpowiednio, jako 1:50 000 i 1:100 000 urodzeń [3, 4]. O częstości występowania postaci wtórnej HLH (sHLH, secondary $H L H$ ), związanej $z$ chorobami nowotworowymi (M-HLH, malignancy-associated $H L H)$, infekcjami (I-HLH, infection-associated $H L H$ ) oraz chorobami autoimmunizacyjnymi, wiadomo jeszcze mniej. Należy podkreślić, że wskaźnik rozpoznań klinicznych jest znacznie niższy niż autopsyjnych [5]. W 30-50\% przypadków sHLH towarzyszy chorobom nowotworowym, z których połowę stanowią chłoniaki [6], a około $40 \%$ przypadków sHLH jest indukowane przez czynnik infekcyjny [7]. W 8-20\% przypadków sHLH obserwuje się u osób z chorobami autoimmunizacyjnymi, zwłaszcza $z$ układowym toczniem rumieniowatym (SLE, systemic lupus erythematous), pod postacią zespołu aktywacji makrofagów (MAS, macrophage-activation syndrome $)[8,9]$.

Ze względu na swój gwałtowny przebieg kliniczny i około 50-procentową śmiertelność sHLH wymaga szybkiego postawienia diagnozy i rozpoczęcia leczenia [10]. Według badań prowadzonych $\mathrm{u}$ dzieci z FLH mediana przeżycia całkowitego (OS, overall survival) bez odpowiedniego leczenia wynosi 2 miesiące, a prawdopodobieństwo 5-letniego OS osiaga jedynie $10 \%$ chorych niepoddanych procedurze allogenicznego przeszczepienia krwiotwórczych komórek macierzystych (allo-HSCT, allogeneic hematopoietic stem cell transplantation) $[11,12]$.

Rozpoznanie HLH jest prawdziwym wyzwaniem dla klinicysty. Objawy są niespecyficzne i często nakładają się na objawy infekcji czy nowo- 
Tabela 1. Kryteria diagnostyczne zespołu limfohistiocytozy hemofagocytarnej (HLH) według Histocyte Society (źródło [15])*

Table 1. Diagnositc criteria for hemophagocytic lymphohisticytosis (HLH) according to the Histocyte Society (sorce [15])*

\begin{tabular}{|l|}
\hline 1. Gorączka \\
\hline 2. Splenomegalia \\
\hline $\begin{array}{l}\text { 3. Cytopenie dotyczące co najmniej } 2 \text { linii komórkowych: } \\
\text { a) stężenie hemoglobiny }<9 \mathrm{~g} / \mathrm{dl} \\
\text { b) liczba płytek krwi }<100 \mathrm{G} / \mathrm{l} \\
\text { c) liczba neutrofilów }<1,0 \mathrm{G} / \mathrm{l}\end{array}$ \\
\hline $\begin{array}{l}\text { 4. Hipertriglicerydemia lub/i hipofibrynogenemia: } \\
\text { a) stężenie triglicerydów } \geq 265 \mathrm{mg} / \mathrm{dl} \\
\text { b) stężenie fibrynogenu } \leq 150 \mathrm{mg} / \mathrm{dl}\end{array}$ \\
\hline $\begin{array}{l}\text { 5. Hemofagocytoza } w \text { szpiku kostnym, śledzionie lub wę- } \\
\text { złach chłonnych }\end{array}$ \\
\hline 6. Niska aktywność komórek NK lub ich brak \\
\hline 7. Stężenie ferrytyny $\geq 500 \mu \mathrm{g} / \mathrm{l}$ \\
\hline $\begin{array}{l}\text { 8. Stężenie rozpuszczalnego receptora IL-2 (sCD25) } \\
\geq 2400 \text { j./ml }\end{array}$ \\
\hline
\end{tabular}

*Rozpoznanie HLH wymaga potwierdzenia obecności mutacji typowej dla HLH lub spełnienia 5 z 8 powyższych kryteriów; IL-2 (interleukin 2) - interleukina 2; NK (natural killers) - komórki naturalnej cytotoksyczności

tworów układu chłonnego, w przebiegu których dochodzi do wystąpienia sHLH. Nie ma żadnego standardowego testu umożliwiającego potwierdzenie obecności choroby, co powoduje, że HLH jest rzadko rozpoznawana $[13,14]$. Obecnie stosuje się kryteria diagnostyczne zaproponowane przez Histiocyte Society [15] w 2004 roku (tab. 1), które są jednak krytykowane $z$ powodu ich niewystarczająco wysokiej swoistości, zwłaszcza u chorych $\mathrm{w}$ ciężkim stanie ogólnym.

\section{Opis przypadku}

Dotychczas zdrowy 36-letni mężczyzna zgłosił się do szpitala rejonowego w czerwcu 2012 roku z powodu trwającej od około 3 tygodni wysokiej gorączki z towarzyszącymi bólami kostno-mięśniowymi i nasiloną potliwością. W tym czasie chory dostrzegł zmniejszenie masy ciała o około $5 \mathrm{~kg}$. Mimo zastosowanej szerokospektralnej antybiotykoterapii nie uzyskano ustąpienia stanów gorączkowych. W ramach rozszerzonej diagnostyki 2-krotnie wykonano tomografię komputerową (CT, computed tomography), która ujawniła niewielką ilość płynu $\mathrm{w}$ obu jamach opłucnowych i jamie otrzewnej oraz rozległe nacieki w obrębie krezki jelita cienkiego i grubego, wokół żołądka, w przestrzeni zaotrzewnowej oraz miednicy mniejszej. Stwierdzono wówczas powiększenie do $20 \mathrm{~mm}$ pojedynczego węzła chłonnego w okolicy krętniczo-kątniczej, powiększenie węzłów chłonnych okołoaortalnych (do $14 \mathrm{~mm}$ ), a także nieznaczne powiększenie wątroby i śledziony. W badaniach krwi stwierdzono umiarkowaną leukopenię (liczba krwinek białych [WBC, white blood count] 3,3 G/1, liczba neutrofilów 2,1 G/1), podwyższenie wskaźników stanu zapalnego (odczyn Biernackiego [OB] $33 \mathrm{~mm} / \mathrm{h}$, stężenie białka C-reaktywnego [CRP, C-reactive protein] $144 \mathrm{mg} / \mathrm{l}$ ) i zwiększoną do $1648 \mathrm{j}$./l aktywność dehydrogenazy mleczanowej (LDH, lactate dehydrogenase). Wobec progresji zmian, zaobserwowanych w badaniu CT, 18 lipca 2012 roku wykonano laparotomię zwiadowczą i śródoperacyjnie stwierdzono obecność dużej ilości wolnego płynu w jamie brzusznej oraz rozlane ogniska zapalne. Pobrano materiał z krezki jelita cienkiego, grubego oraz fragment sieci. Wnioski $z$ badań histopatologicznych były niejednoznaczne i trudne do różnicowania między chłoniakiem nie-Hodgkina $z$ komórek T (T-NHL, T-cell non-Hodgkin lymphoma) a chorobami o podłożu autoimmunizacyjnym. W ciagu kolejnych 2 tygodni doszło u chorego do powiększenia pachwinowych węzłów chłonnych po prawej stronie. W celu doprecyzowania rozpoznania 7 sierpnia 2012 roku pobrano jeden $z$ powiększonych pachwinowych węzłów chłonnych. W badaniu histopatologicznym opisano utkanie węzła chłonnego $z$ cechami zmian odczynowych, w obrębie przegród tkanki tłuszczowej naciek $z$ atypowych komórek limfoidalnych, pojedynczych granulocytów oraz obecność ognisk martwicy. Na podstawie obrazu mikroskopowego i badań immunohistochemicznych histopatolog wysunął podejrzenie T-NHL (CD3+, CD20-, Ki-67+ $\mathrm{w}$ około $40 \%$ komórek, CD30+ w pojedynczych komórkach).

Ze względu na niejasne rozpoznanie w sierpniu 2012 chory został przyjęty do Kliniki Hematologii Instytutu Hematologii i Transfuzjologii (IHT) w celu uzupełnienia diagnostyki. Przy przyjęciu chory był $\mathrm{w}$ dobrym stanie mimo utrzymującej się gorączki do $39^{\circ} \mathrm{C}$. Wzrostowi temperatury towarzyszyły pojawianie się na skórze czoła wysypki plamisto-grudkowej oraz występowanie silnych dolegliwości bólowych stawów skokowych. Nie stwierdzono powiększenia obwodowych węzłów chłonnych; w dołach pachowych palpacyjnie był wyczuwalny naciek $\mathrm{w}$ tkance podskórnej. W badaniu CT stwierdzano: niewielką ilość płynu $(15 \mathrm{~mm}) \mathrm{w}$ prawej jamie opłucnowej, w osierdziu, w jamie otrzewnowej; powiększoną wątrobę $(190 \mathrm{~mm})$; granicznej wielkości śledzionę $(125 \mathrm{~mm})$. Nie uwidoczniono limfadenopatii ani opisywanych wcześniej nacieków w obrębie jamy brzusznej i miednicy mniejszej. W morfologii krwi obwodowej 
nadal stwierdzano umiarkowaną leukopenię (WBC 3,1 G/l) z przewagą neutrofilów $(2,4 \mathrm{G} / \mathrm{l})$ oraz nieznaczną niedokrwistość mikrocytową (stężenie hemoglobiny [Hb] 11,4 g/dl, średnia objętość krwinki [MCV, mean corpuscular volume] $80 \mathrm{fl}$ ). $\mathrm{W}$ badaniach biochemicznych obserwowano umiarkowane podwyższenie aktywności enzymów wątrobowych i stężenia CRP, znacznie zwiększone aktywność LDH (1800-4600 j./l) i stężenie ferrytyny (11 000-27 000 ng/ml) oraz obniżone stężenie haptoglobiny. Stężenie triglicerydów wynosiło $304 \mathrm{mg} / \mathrm{dl}$. W badaniach układu krzepnięcia obserwowano podwyższone do $5,5 \mathrm{~g} / 1$ stężenie fibrynogenu. Wyniki badań przesiewowych w kierunku chorób układowych tkanki łącznej, tj. przeciwciał antycytoplazmatycznych (ANCA, anti-neutrophil cytoplasmic antibodies) i antycytrulinowych (anty-CCP [cyclic citrullinated peptide]), były negatywne, przeciwciała przeciwjądrowe (ANA, anti-nuclear antibodies) występowały w granicznym mianie 1:100. Wykluczono aktywne infekcje bakteryjną, grzybiczą i wirusową. Wykonano badania cytologiczne i immunofenotypowe oraz trepanobiopsję szpiku, w których nie stwierdzono istotnych odchylen, w tym cech hemofagocytozy.

W badaniu ultrasonograficznym (USG) jamy brzusznej opisano mierne powiększenie śledziony $(158 \mathrm{~mm})$ oraz powiększenie wątroby $(185 \mathrm{~mm})$ w wymiarze podłużnym prawego płata. W Pracowni Patomorfologii IHT ponownie oceniono preparaty $z$ wycinków $z$ krezki i węzłów chłonnych pobranych wcześniej. Ze względu na trudności interpretacyjne nie można było jednoznacznie potwierdzić ani wykluczyć T-NHL. Immunohistochemicznie i klinicznie obraz mógł odpowiadać podskórnemu chłoniakowi T-komórkowemu o typie panniculitis-like (SPTCL, subcutaneous panniculitis-like T-cell lymphoma) $\mathrm{z}$ nietypową lokalizacją $\mathrm{w}$ tkance tłuszczowej krezki. $Z$ materiału archiwalnego $z$ bloczków parafinowych nie udało się wykonać badania klonalnej rearanżacji genów kodujących receptor T-komórkowy (TCR, T-cell receptor), a wynik badania wykonanego $z$ aspiratu szpiku kostnego był negatywny. Dodatkowo pobrano wycinki skóry i tkanki podskórnej z okolicy lewego dołu pachowego, w którym w badaniu histopatologicznym obraz był podobny do obserwowanego we wcześniejszych wycinkach. W podskórnej tkance tłuszczowej widoczne były nacieki $z$ małych i średniej wielkości limfocytów $\mathrm{T}$ o fenotypie $\mathrm{CD} 3+, \mathrm{CD} 8+$, $\mathrm{CD} 4-, \mathrm{CD} 7+, \mathrm{CD} 5+/-\mathrm{z}$ tapetowaniem adipocytów. Towarzyszyły im liczne makrofagi (CD163+) fagocytujące debris komórkowe i erytrocyty oraz dość liczne komórki plazmatyczne (ryc. 1).
W diagnostyce różnicowej brano pod uwagę chłoniaka $\mathrm{z}$ komórek $\mathrm{T}$ tkanki podskórnej typu zapalenia tkanki podskórnej oraz zapalenie podskórnej tkanki tłuszczowej spotykane w chorobach autoimmunizacyjnych. W badanym materiale nie wykazano rearanżacji genów kodujących TCR, co wskazywało raczej na poliklonalny/odczynowy charakter obserwowanych zmian naciekowych.

Przebieg kliniczny i wyniki badań dodatkowych, w tym histopatologicznych i genetycznych, nie pozwalały na jednoznaczne rozpoznanie ani T-NHL ani układowej choroby tkanki łącznej. $Z$ powodu obecności płynu w jamach surowiczych, bólu gardła, stanów gorączkowych, osutki na skórze w czasie gorączki i bólów stawów skokowych oraz znacznie podwyższonego stężenia ferrytyny w różnicowaniu brano pod uwagę chorobę Stilla. Zdecydowano o włączeniu metylprednizolonu początkowo w dawce $250 \mathrm{mg} /$ dobę, a następnie $100 \mathrm{mg}$ /dobę. Po 2 tygodniach uzyskano ustapienie gorączki, znaczne zmniejszenie się ilości płynu $\mathrm{w}$ jamie otrzewnej, regresję nacieków w tkance podskórnej w dołach pachowych oraz obniżenie wykładników stanu zapalnego. Chorego zakwalifikowano do dalszej obserwacji w kierunku T-NHL lub niesklasyfikowanej choroby tkanki łącznej i wypisano $z$ zaleceniem kontynuacji steroidoterapii - prednizonu w dawce $60 \mathrm{mg} /$ dobę.

Chorego przyjęto ponownie do Kliniki Hematologii IHT w październiku 2012 roku z powodu utrzymującej się od około 2 tygodni wysokiej gorączki, sięgającej nawet $42^{\circ} \mathrm{C}$, mimo kontynuacji leczenia prednizonem $\mathrm{w}$ niezmienionej dawce $60 \mathrm{mg} /$ dobę. Przy przyjęciu pacjent zgłaszał ból gardła, nudności i wymioty. $\mathrm{W}$ badaniu przedmiotowym stwierdzono zaczerwienione, powiększone migdałki $z$ nalotami ropnymi. $Z$ wymazu $z$ gardła, nosa oraz posiewu krwi wyhodowano Staphyloccocus aureus MRSA (methicillin resistance among Staphylococcus aureus). U pacjenta zastosowano celowaną antybiotykoterapię i uzyskano ustąpienie gorączki. Utrzymano steroidoterapię metylprednizolonem w dawce $50 \mathrm{mg}$ /dobę. W wykonanym badaniu CT obserwowano obraz podobny do wyniku $z$ sierpnia 2012 roku, $z$ utrzymującym się powiększeniem wątroby, śledziony, naciekami w tkankach miękkich obu dołów pachowych i zwiększoną gęstością w otrzewnej tkance tłuszczowej. Ponownie wykonano badania cytologiczne i immunofenotypowe szpiku, nie stwierdzając cech nowotworu układu chłonnego. Po krótkotrwałej poprawie i ustąpieniu objawów klinicznych stan chorego uległ pogorszeniu. Nastąpił wzrost temperatury do $40^{\circ} \mathrm{C}$ przy jalowych posiewach krwi. W badaniach dodatkowych 


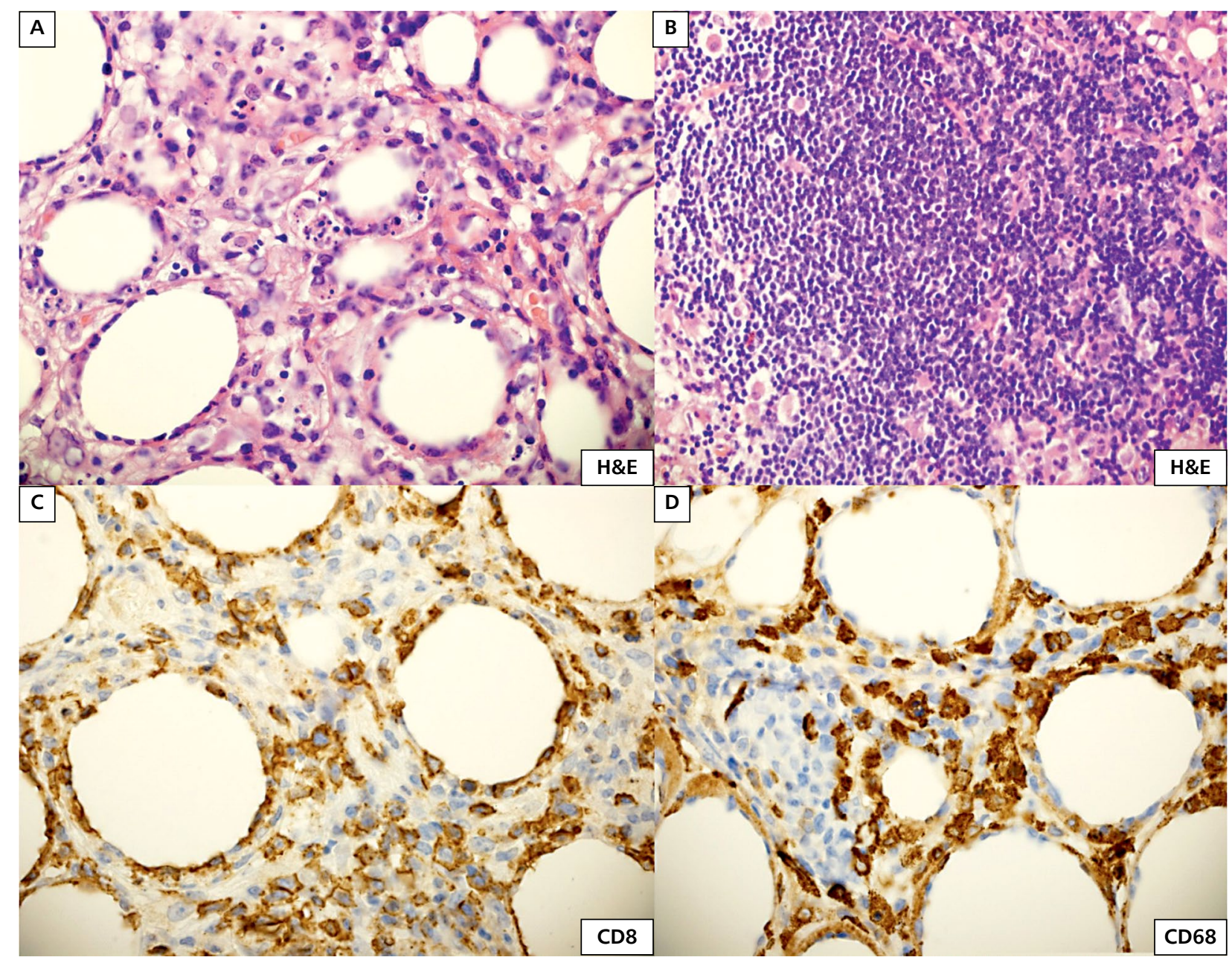

Rycina 1A-D. Nacieki limfohistiocytarne w tkance tłuszczowej: A. Nacieki z limfocytów i makrofagów fagocytujących debris komórkowe, widoczne tapetowanie komórek tłuszczowych przez limfocyty; B. Grudka chłonna; C. Limfocyty T wykazujące ekspresję CD8; D. Liczne makrofagi (CD68+) w naciekach. Barwienie hematoksyliną i eozyną (H\&E) (A i B), barwienie EnVision (C i D), powiększenie $400 \times$

Figure 1A-D. Lymphohistiocytic infiltration in adipose tissue: A. Lymphocytes and macrophages containing apoptotic debris; lymphocytes surround fat cells; B. Lymphoid nodule; C. Lymphocytes T with expression CD8; D. Numerous macrophages $(\mathrm{CD} 68+)$ inside the infiltration. Hematoxylin \& eosin staining (H\&E) (A and B), EnVision staining (C and D), magnification $400 \times$

obserwowano pogłębiającą się leukopenię $(1,27$ $\mathrm{G} / \mathrm{l}) \mathrm{z}$ neutropenią $(0,7 \mathrm{G} / \mathrm{l})$, niedokrwistość $(\mathrm{Hb}$ $10,4 \mathrm{~g} / \mathrm{dl}$ ), podwyższoną aktywność transaminaz (aminotransferazy asparaginianowej [AST, aspartate aminotransferase ] $273 \mathrm{j} . / 1$, aminotransferazy alaninowej [ALT, alanine aminotransferase $163 \mathrm{j} . / 1$ ), LDH (6777 j./l), stężenie triglicerydów (304 mg/dl), obniżone stężenie fibrynogenu $(0,5 \mathrm{~g} / \mathrm{l})$, wysokie stężenie ferrytyny $(32608 \mathrm{ng} / \mathrm{ml})$. Na podstawie obrazu klinicznego i wyników badań dodatkowych, tj. splenomegalii, neutropenii, hiperferrytynemii, hipofibrynogenemii, hipertriglicerydemii, rozpoznano HLH. Rozpoczęto leczenie chorego według programu HLH-1994 (10 podań etopozydu $\mathrm{w}$ dawce $150 \mathrm{mg} / \mathrm{m}^{2}$ dożylnie (i.v., intravenous), deksametazon $10 \mathrm{mg} / \mathrm{m}^{2}$ i.v. przez pierwsze 2 tygodnie, następnie $\mathrm{w}$ zmniejszonych dawkach przez kolejne 6 tygodni oraz $6 \mathrm{mg} / \mathrm{kg} \mathrm{mc}$. CsA w 2 dawkach podzielonych/d. od 9 . tygodnia leczenia $z$ dostosowaniem dawki, tak aby utrzymać stężenie cyklosporyny w surowicy wynoszące $200 \mathrm{ng} / \mathrm{ml}$ ). Wykluczono zajęcie ośrodkowego układu nerwowego (OUN), tj. nie stwierdzono istotnych odchyleń w badaniu neurologicznym, w badaniu immunofenotypowym płynu mózgowo-rdzeniowego ani w badaniu mózgu metodą rezonansu magnetycznego (MRI, magnetic resonance imaging). Po wdrożeniu leczenia obserwowano stopniową poprawę stanu 
ogólnego chorego. Uzyskano ustąpienie stanów gorączkowych, normalizację aktywności enzymów wątrobowych, stężenia fibrynogenu, zmniejszenie stężenia ferrytyny oraz poprawę morfologii krwi. Leczenie CsA kontynuowano ambulatoryjne. W kolejnych ocenach w Klinice w styczniu i maju 2013 roku oraz w trakcie kolejnych wizyt w Poradni Hematologicznej IHT stwierdzano prawidłowe parametry morfologii krwi obwodowej, stężenia ferrytyny i fibrynogenu, nieznacznie podwyższoną aktywność transaminaz i LDH. Ostatecznie wykluczono obecność nowotworu układu chłonnego. W styczniu 2014 roku zakończono leczenie CsA, a pacjent pozostawał pod obserwacją w Poradni Hematologicznej IHT.

Po upływie roku, tj. w styczniu 2015 roku, chory wymagał ponownej hospitalizacji $z$ powodu stanów gorączkowych do $40^{\circ} \mathrm{C}$ niepoddających się leczeniu doustnym antybiotykiem. Przy przyjęciu do Kliniki Hematologii IHT chory był w dobrym stanie ogólnym. W badaniu przedmiotowym nie stwierdzano istotnych odchyleń od stanu prawidłowego. Wyniki badań dodatkowych odpowiadały nawrotowi HLH: WBC 2,01 G/l, liczba neutrofilów $1,12 \mathrm{G} / 1$, stężenie $\mathrm{Hb}$ 13,3 g/dl, liczba płytek krwi $248 \mathrm{G} / 1$, stężenie triglicerydów $466 \mathrm{mg} / \mathrm{dl}$, stężenie ferrytyny $7285 \mathrm{ng} / \mathrm{ml}$, stężenie fibrynogenu $0,63 \mathrm{~g} / \mathrm{l}$. W USG jamy brzusznej zobrazowano powiększenie śledziony (165 mm). Ponadto stwierdzono wzrost aktywności enzymów wątrobowych: ALT $116 \mathrm{j} . / \mathrm{l}$, AST 120 j./l, LDH 2785 j./l. Przeprowadzono ponowną diagnostykę $\mathrm{w}$ kierunku nowotworów układu chłonnego (CT, trepanobiopsja, cytometria przepływowa, klonalność limfocytów T), ale wyniki badań nie potwierdziły ich obecności. W posiewach krwi wyhodowano Staphylococcus hominis. Mimo zastosowania celowanej antybiotykoterapii utrzymywały się stany gorączkowe i obserwowano narastanie cech HLH. Zdecydowano o powtórnym wdrożeniu leczenia według programu HLH-1994 i jednocześnie kontynuowano antybiotykoterapię, leczenie przeciwgrzybicze, stosowano czynnik wzrostu kolonii granulocytów (G-CSF, granulocyte-colony stimulating factor) i immunoglobuliny dożylne (IVIG, intravenous immunoglobulin) oraz wyrównywano zaburzenia krzepnięcia. W kolejnych dniach obserwowano stopniowy spadek gorączki, obniżenie wskaźników zapalnych i poprawę parametrów krzepnięcia. Leczenie było powikłane zapaleniem błon śluzowych jamy ustnej, wzrostem ciśnienia tętniczego wymagającym stosowania leków hipotensyjnych oraz zaburzeniami lipidowymi. $Z$ powodu nawrotowego charakteru HLH chorego zakwalifikowano do procedury allo-HSCT. $Z$ po- wodu braku dawcy rodzinnego w marcu 2015 roku rozpoczęto poszukiwania dawcy niespokrewnionego, którego w pełni dobrano w zakresie zgodności ludzkich antygenów leukocytarnych (HLA, human leukocyte antigens) na początku maja 2015 roku.

W kwietniu 2015 roku rozpoznano u chorego kolejny nawrót HLH z typowymi objawami klinicznymi i odchyleniami w badaniach dodatkowych. W kilkakrotnie wykonywanych posiewach krwi nie obserwowano wzrostu bakterii ani grzybów. Ze względu na towarzyszące cechy znacznego uszkodzenia wątroby (ALT $732 \mathrm{j} . / 1$, AST 548 j./l) odstawiono leki potencjalnie hepatotoksyczne, $\mathrm{w}$ tym CsA. Ponownie rozpoczęto leczenie według programu HLH-1994, z pominięciem CsA, uzyskując ustąpienie gorączki oraz normalizację wskaźników laboratoryjnych HLH. Chorego w dobrym stanie ogólnym wypisano do domu pod koniec maja 2015 roku.

8 czerwca 2015 roku pacjent został przyjęty do Kliniki Transplantacji Komórek Krwiotwórczych IHT w celu wykonania allo-HSCT od w pełni zgodnego w zakresie HLA dawcy polskiego. Dawcą był 39-letni mężczyzna identyczny $z$ biorcą pod względem grup krwi oraz statusu serologicznego wirusa cytomegalii (CMV, cytomegalovirus) (zarówno u biorcy, jak i dawcy były obecne przeciwciała anty-CMV w klasie IgG). Chorego poddano kondycjonowaniu składającemu się fludarabiny w dawce $150 \mathrm{mg} /$ $/ \mathrm{m}^{2}$ podawanej przezskórnie (p.c., percutaneous), melfalanu w dawce $140 \mathrm{mg} / \mathrm{m}^{2}$ p.c., cyklofosfamidu w dawce $30 \mathrm{mg} / \mathrm{kg} \mathrm{mc}$. oraz globuliny antylimfocytowej (tymoglobuliny) w dawce $4,5 \mathrm{mg} / \mathrm{kg} \mathrm{mc}$. Szpik kostny, w ilości 3,2 $\times 10^{8}$ komórek jednojądrzastych, zawierający $1,6 \times 10^{6}$ komórek CD34+/kg mc., przeszczepiono 17 czerwca 2015 roku. Jako profilaktykę choroby przeszczep przeciw gospodarzowi (GvHD, graft versus host diseaase) stosowano metotreksat (MTX) oraz CsA w standardowych dawkach. Wszczepienie wspomagane filgrastimem osiagnięto $\mathrm{w}+15$. dobie po transplantacji. $\mathrm{W}+14$. dobie po przeszczepieniu wystąpił krwiomocz $z$ nasilonymi dolegliwościami bólowymi przy mikcji. W USG uwidoczniono pogrubiałą ścianę pęcherza $z$ obecnością skrzepów krwi w jego świetle. Chory wymagał stosowania narkotycznych leków przeciwbólowych oraz forsowanej diurezy $z$ założeniem trójdrożnego cewnika do pęcherza i płukaniem solą fizjologiczną. Jednocześnie wystąpiły stany gorączkowe do $38,6^{\circ} \mathrm{C}$. W badaniach diagnostycznych wykluczono bakteryjne zakażenie dróg moczowych, stwierdzono natomiast obecność DNA wirusa BK (BKV, $B K$ virus) oraz DNA adenowirusa (ADV, adenovirus) w próbkach moczu oraz krwi. Wdrożono leczenie 
cydofowirem w dawce $5 \mathrm{mg} / \mathrm{kg} \mathrm{mc}$. wraz z probenecydem co 7 dni. Całkowite ustąpienie stanów gorączkowych osiagnięto po tygodniu od podania pierwszej dawki leku przeciwwirusowego. Zmniejszenie nasilenia krwiomoczu i dolegliwości bólowych zaobserwowano dopiero po 4 . dawce cydofowiru. $\mathrm{W}+46$. dobie po transplantacji wykonano badanie chimeryzmu hematopoetycznego metodą polimerazy lańcuchowej (PCR, polymerase chain reaction) służącej do oceny sekwencji mikrosatelitarnych, nazywane krótkimi tandemowymi powtórzeniami (STR, short tandem repeats) w komórkach jednojądrzastych krwi obwodowej, które ujawniło 56\% DNA dawcy. Z tego powodu oraz utrzymywania się zapalenia pęcherza o etiologii ADV/BKV zdecydowano o wstrzymaniu leczenia immunosupresyjnego CsA. W efekcie całkowite ustąpienie objawów zapalenia pęcherza uzyskano po kolejnych 13 dniach. Chorego wypisano do domu w dobrym stanie ogólnym $\mathrm{w}+64$. dobie po transplantacji. $W+84$. dobie, podczas wizyty kontrolnej w Poradni Potransplantacyjnej IHT, rozpoznano ostrą GvHD o manifestacji wyłącznie skórnej o typie wysypki plamisto-grudkowej z zajęciem około $50 \%$ powierzchni ciała. Wdrożono leczenie ambulatoryjne metylprednizolonem w dawce $1 \mathrm{mg} /$ /kg mc. $z$ szybkim ustąpieniem objawów i całkowitym odstawieniem po 6 tygodniach. W badaniach kontrolnych $\mathrm{w}+100$. dobie po allo-HSCT oraz kolejnych, powtarzanych co 3 miesiące, obserwowano pełną regenerację hematologiczną oraz 100-procentowy chimeryzm dawcy w komórkach jednojądrzastych krwi obwodowej. Obecnie, 20 miesięcy po allo-HSCT, pacjent pozostaje w remisji HLH, bez objawów niepożądanych związanych $z$ przeszczepieniem i od niemal roku kontynuuje pracę zawodową.

\section{Dyskusja}

Prezentowany przypadek jest przykładem sHLH najprawdopodobniej wywołanej zakażeniem bakteryjnym. W trakcie pierwszej hospitalizacji nie rozpoznano u chorego HLH; nie było spełnionych co najmniej 5 z 8 kryteriów według Histicyte Society. Celem prowadzonej diagnostyki było przede wszystkim wykluczenie lub potwierdzenie T-NHL albo choroby autoimmunizacyjnej. Chociaż pacjent został przyjęty do IHT ze stanami gorączkowymi, to od wielu dni otrzymywał szerokospektralną antybiotykoterapię, co najprawdopodobniej było przyczyną negatywnych wyników badań mikrobiologicznych. Dopiero w trakcie drugiej hospitalizacji potwierdzono rozpoznanie HLH, wykryto obecność Staphylococcus aureus MRSA w górnych drogach oddechowych i we krwi, co uznano za prawdopodobny czynnik etiologiczny HLH.

W sHLH kluczowe jest ustalenie przyczyny. Wtórna postać HLH najczęściej występuje w przebiegu takich chorób nowotworowych, jak NHL i białaczki $z$ komórek T/NK, chłoniak rozlany $z$ dużych komórek B (DLBCL, diffuse large B-cell lymphoma), chłoniak Hodgkina (HL, Hodgkin lymphoma) i ostre białaczki szpikowe $[10,16]$.

Wśród sHLH indukowanej zakażeniami $40 \%$ stanowią infekcje wirusowe, najczęściej wirusem Epstein-Barr (EBV, Epstein-Barr virus) i CMV, ale może również towarzyszyć zakażeniom ludzkim wirusem nabytego niedoboru odporności (HIV, $h u$ man immunodeficiency virus), parwowirusem, wirusami zapalenia wątroby $\mathrm{A} \mathrm{i} \mathrm{C,} \mathrm{wirusem} \mathrm{opryszcz-}$ ki pospolitej (HSV, herpes simplex virus), ludzkim wirusem opryszczki (HHV, human herpesvirus), grypy, różyczki i odry. Wśród infekcji bakteryjnych połowę przypadków sHLH stwierdza się w zakażeniach Mycobacterium sp., w pozostałych najczęściej czynnikiem etiologicznym jest zakażenie Staphylococcus aureus lub Escherichia coli. W przypadkach zakażeń grzybiczych sHLH częściej towarzyszy infekcjom Histoplasma capsulatum i Pneumocystis species [7, 14, 17]. W tabeli 2 przedstawiono czynniki etiologiczne mogące wywołać sHLH [14]. Należy podkreślić, że nawet w przypadku obecności infekcji pacjent wymaga szczegółowej diagnostyki wykluczającej chorobę nowotworową, jak to miało miejsce w prezentowanym przypadku.

Wtórna HLH jako MAS najczęściej towarzyszy takim chorobom autoimmunizacyjnym, jak młodzieńcze zapalenie stawów (50\% przypadków), SLE (22\%), choroba Stilla (9\%), choroba Kawasaki (6\%) i pojedynczym przypadkom zapalenia skórno-mięśniowego, twardziny układowej i mieszanej choroby tkanki łącznej [8, 9]. Warto podkreślić, że prawie połowa pacjentów, u których rozwinęła się sHLH, była w stanie immunosupresji (leczenie immunosupresyjne, zakażenie HIV) [18].

Patomorfologiczna diagnostyka różnicowa między SPTCL i zapaleniem tkanki podskórnej $\mathrm{w}$ chorobach autoimmunizacyjnych jest trudna, a w niektórych przypadkach niemożliwa. Sugeruje się, że te dwie choroby stanowią spektrum dyskrazji z limfocytów T typu zapalenia tkanki podskórnej. Obecność pasmowatych nacieków z pleomorficznych cytotoksycznych limfocytów T i wysoki indeks proliferacyjny są cechami SPTCL, natomiast obecność nacieków z komórek plazmatycznych, grudek chłonnych oraz plazmocytoidnych komórek dendrytycznych przemawia raczej za rozpoznaniem zmian zapalnych. Potwierdzenie 
Tabela 2. Przyczyny wtórnej limfohistiocytozy hemofagocytarnej (źródło [14])

Table 2. Causes of secondary hemophagocytic lymphohisticytosis (source [14])

\begin{tabular}{|c|}
\hline Infekcyjne \\
\hline $\begin{array}{l}\text { Wirusowe: z grupy herpes (EBV, CMV, HHV-8, HSV), HIV, HTLV, adenowirus, wirusy zapalenia wątroby (HAV, HBV, HCV), } \\
\text { parwowirus B19, wirusy grypy, H1N1, odry, świnki, różyczki enterowirus, flawiwirus (gorączka denga), hantawirus }\end{array}$ \\
\hline $\begin{array}{l}\text { Bakteryjne: Staphylococcus aureus, Campylobacter spp., Fusobacterium spp., Mycoplasma spp., Chlamydia spp., Legionella } \\
\text { spp., Salmonella typhi, Rickettsia spp., Brucella spp., Ehrlichia spp., Borrelia burgdorferi, Mycobacterium tuberculosis }\end{array}$ \\
\hline $\begin{array}{l}\text { Pasożytnicze: Leishmania spp., Plasmodium spp. (vivax, falciparum), Toxpolasma spp., Strongyloides spp., Spirochetes spp., } \\
\text { Babesia spp. }\end{array}$ \\
\hline Grzybicze: Candida spp., Cryptococcus spp., Pneumocystis spp., Histoplasma spp., Aspergillus spp., Fusarium spp. \\
\hline Związane z chorobą nowotworową \\
\hline $\begin{array}{l}\text { Hematologiczne: chłoniaki (z limfocytów T/NK, z obwodowych limfocytów T, anaplastyczny, klasyczny chłoniak Hodgkina, } \\
\text { z komórek B), ostre białaczki, szpiczak plazmocytowy }\end{array}$ \\
\hline Niehematologiczne: rak wątrobowokomórkowy, rak prostaty, rak płuc \\
\hline Związane z chorobą autoimmunizacyjną — zespół aktywacji makrofagów (MAS) \\
\hline $\begin{array}{l}\text { Młodzieńcze zapalenie stawów, choroba Stilla, toczeń układowy, choroba Kawasaki, reumatoidalne zapalenie stawów, } \\
\text { seronegatywne zapalenie stawów }\end{array}$ \\
\hline Inne: leki, ciąża, zabiegi operacyjne, hemodializy, szczepienia, wrzodziejące zapalenie jelita grubego \\
\hline
\end{tabular}

klonalnej rearanżacji genów TCR silnie przemawia za rozpoznaniem chłoniaka. W obu jednostkach może występować zespół hemofagocytarny [19-21].

Objawy, które sugerowały rozpoznanie sHLH $\mathrm{u}$ opisanego chorego, to przede wszystkim uporczywa gorączka, będąca wynikiem wysokich stężeń interleukin (IL) prozapalnych, zapalenie wątroby spowodowane nacieczeniem narządu przez makrofagi i limfocyty, a manifestujące się podwyższonymi wartościami transaminaz oraz znacznie podwyższone stężenie ferrytyny (>30 $000 \mathrm{ng} / \mathrm{ml}$ ), będące wynikiem wychwytywania hemu przez zaktywowane makrofagi [22]. Wysokie stężenie ferrytyny, przekraczające $10000 \mathrm{ng} / \mathrm{ml}$, charakteryzuje się wysoką czułością (90\%) i specyficznością (96\%) w HLH [23, 24], natomiast prawidłowe stężenie ferrytyny wykazuje najwyższą negatywną wartość predykcyjną w tej chorobie [25]. Kolejne kryteria HLH, które spełniał pacjent, to hipertriglicerydemia, wtórna do zmniejszenia aktywności lipazy lipoproteinowej pod wplywem czynnika martwicy nowotworów $\alpha$ (TNF $\alpha$, tumor necrosis factor alpha), hipofibrynogenemia, powstała w wyniku aktywacji fibrynolizy przez uwalniany z makrofagów aktywator plazminogenu, oraz dwuukładowa cytopenia (neutropenia i małopłytkowość), spowodowana działaniem cytokin, takich jak TNF $\alpha$ i interferon $\gamma$ (IFN $\gamma)$. W aspiracie szpiku nie stwierdzono obecności hemofagocytozy, ale nie wyklucza to rozpoznania HLH. Obecność hemofagocytozy jako markera HLH ma niską czułość i swoistość, dotyczy tylko $60 \%$ chorych i może tė̇ występować w innych stanach chorobowych [26-28]. Podczas diagnostyki chorego nie było możliwości oznaczenia stężenia rozpuszczalnego receptora dla IL-2 (sCD25), aktywności komórek NK ani wykonania badań genetycznych na obecność znanych mutacji występujących w pierwotnej HLH. Badania sCD25 czy test uwalniania radioaktywnego chromu $\left({ }^{51} \mathrm{Cr}\right)$, służącego do oceny aktywności komórek NK, są dostępne tylko w wysokospecjalistycznych laboratoriach [14]. U chorego nie obserwowano objawów neurologicznych; badanie płynu mózgowo-rdzeniowego i MRI mózgu nie wskazywały na zajęcie OUN. Nacieczenie OUN przez limfocyty i histiocyty oraz hemofagocytoza mogą wystąpić w 20-50\% przypadków HLH [29].

Rozpoznanie HLH wymaga dużego doświadczenia klinicznego. Jak już wspomniano, objawy i kryteria diagnostyczne HLH mogą być podobne do objawów występujących w nowotworach układu chłonnego, w zespole ogólnoustrojowej reakcji zapalnej (SIRS, systemic inflammatory response syndrome), w posocznicy czy w zespole niewydolności wielonarządowej (MODS, multiorgan dysfunction syndrome). Dlatego decyzja o rozpoznaniu i rozpoczęciu leczenia jest oparta raczej na „mocnym” podejrzeniu klinicznym $z$ wykluczeniem innych schorzeń niż na jednoznacznych dowodach. Oczekiwanie na wyniki badań nie powinno 
Tabela 3. Protokół leczenia HLH-1994 według Histiocyte Society (źródło [11])

Table 3. The treatment protocol for HLH-1994 according to the Histiocyte Society (source [11])

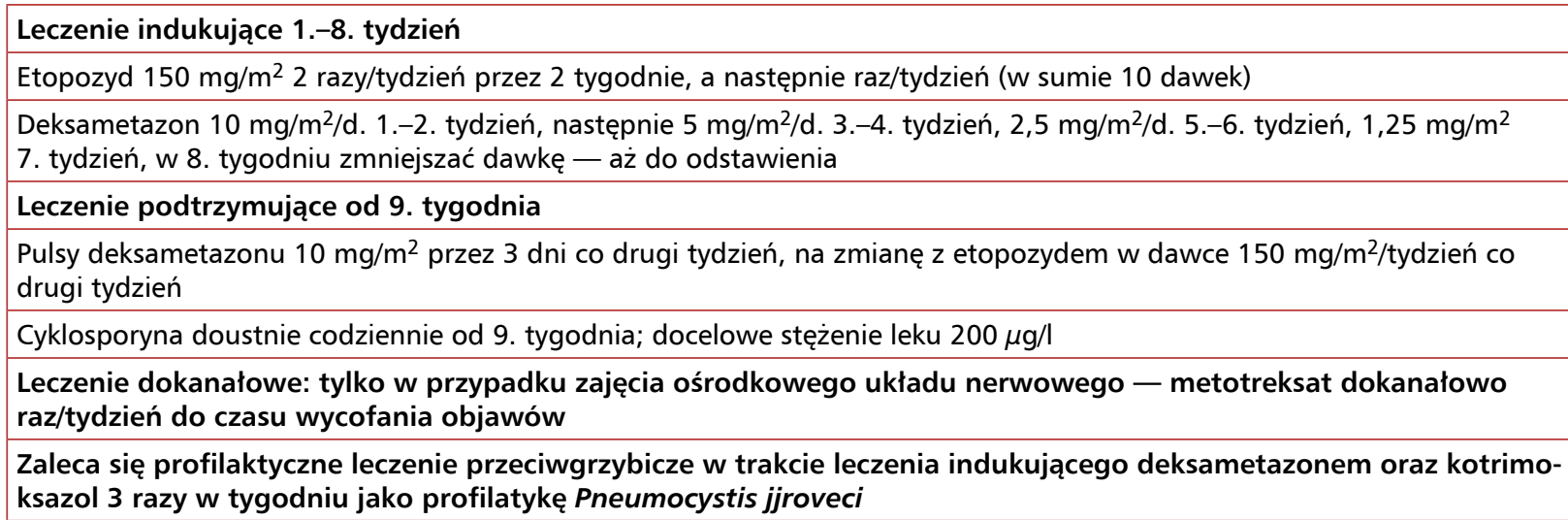

opóźniać wdrożenia właściwej terapii. Niezwykle ważne jest, aby leczenie rozpocząć zanim hipercytokinemia spowoduje nieodwracalne zmiany w narządach.

Terapia HLH powinna jednocześnie obejmować intensywne leczenie objawowe związane $z$ ciężkością stanu ogólnego, leczenie eliminujące czynnik wywołujący sHLH lub chorobę podstawową oraz supresję nadmiernej reakcji zapalnej [28]. W leczeniu objawowym stosuje się przede wszystkim przetoczenia preparatów krwiopochodnych i koncentratów czynników krzepnięcia w przypadku wystąpienia koagulopatii i małopłytkowości, profilaktykę przeciwbakteryjną i przeciwgrzybiczą, leczenie wtórnych zakażeń, wyrównywanie zaburzeń wodno-elektrolitowych i metabolicznych oraz intensywną terapię w przypadkach niewydolności oddechowej, krążenia, nerek i wątroby. Należy pamiętać, że użycie czynników wzrostu, takich jak G-CSF, w aktywnej HLH może zaostrzyć przebieg choroby [28, 30].

Jak pokazał przebieg kliniczny sHLH w przypadku opisanego chorego, antybiotykoterapia i eliminacja czynnika infekcyjnego nie wystarczają do wygaszenia nadmiernej odpowiedzi immunologicznej. Przyczyną nieprawidłowej reakcji zapalnej są zaburzenia funkcji komórek NK i limfocytów T, dlatego też postępowanie terapeutyczne obejmuje głównie immunomodulacyjne i cytotoksyczne oddziaływania na te komórki. Nie ma prospektywnych badań dotyczących leczenia HLH u osób dorosłych. Schematy leczenia opracowane przez Francuską Grupę Pediatryczną HLH [31] czy międzynarodową grupę badawczą Histiocyte Society dotyczyły pacjentów pediatrycznych, u których najczęściej występuje postać FLH.

Francuska Grupa Pediatryczna HLH zaleca przede wszystkim leczenie immunosupresyjne obejmujące stosowanie metylprednizolonu w dawce początkowej od 2 do $5 \mathrm{mg} / \mathrm{kg}$ mc., następnie zmniejszanej w ciągu 2 tygodni, króliczej surowicy antytymocytarnej (ATG, antithymocyte globulin) w dawce $10 \mathrm{mg} / \mathrm{kg} \mathrm{mc}$. przez $5 \mathrm{dni}$ oraz CsA od 16. dnia w dawce $150-200 \mathrm{ng} / \mathrm{ml}$, pod kontrolą stężenia leku w surowicy, i później jako leczenia podtrzymującego. W przypadku zajęcia OUN podaje się MTX dokanałowo (i.t., intrathecal) raz $\mathrm{w}$ tygodniu $\mathrm{w}$ dawce zależnej od wieku pacjenta przez 5-6 tygodni [31].

Schematem, który wykorzystano w leczeniu opisanego pacjenta, jest protokół HLH-1994 opracowany przez Histiocyte Society (tab. 3). Podstawowa terapia HLH obejmuje leczenie etopozydem w połączeniu $z$ deksametazonem i CsA [11]. Etopozyd jest inhibitorem topoizomerazy II i w selektywny sposób usuwa limfocyty T, prowadząc do supresji cytokin prozapalnych i poprawy przeżycia w HLH. Johnson i wsp. uważają, że to właśnie deplecja limfocytów T, a nie zahamowanie ich aktywacji, jest najbardziej efektywnym mechanizmem leczenia HLH [32]. Potwierdzają to Imashuku i wsp., którzy wykazali, że u pacjentów $z$ HLH indukowanym przez infekcję EBV leczonych glikokortykosteroidami, immunoglobulinami, CsA lub kombinacją tych leków wskaźniki przeżycia były znacząco gorsze niż u chorych otrzymujących etopozyd [33]. Mimo potencjalnego ryzyka włączenie etopozydu na wczesnym etapie HLH dodatkowo jeszcze poprawiało wskaźniki przeżycia tych chorych [33].

Należy jednak podkreślić, że nie oceniano skuteczności ani toksyczności schematów HLH1994 i HLH-2004 u osób dorosłych. Ze względu na większą neurotoksyczność CsA u dorosłych chorych [34] La Rosée i wsp. twierdzą, że w tej grupie schemat HLH-1994 może być korzystniejszy, 
ponieważ CsA nie podaje się w ciągu pierwszych 8 tygodni leczenia, jak to ma miejsce w przypadku schematu HLH-2004 [35]. Z tego powodu u opisanego chorego zastosowano schemat HLH-1994.

Dostosowanie dawki do wieku pacjenta dotyczy też etopozydu. $Z$ mniejszenie dawki do $100 \mathrm{mg} / \mathrm{m}^{2}$, a nawet $50 \mathrm{mg} / \mathrm{m}^{2}$ u pacjentów starszych jest uzasadnione przedłużonym działaniem mielosupresyjnym etopozydu i wzrostem ryzyka wtórnych infekcji. W przypadku nasilonych objawów cholestazy dawkę należy zmniejszyć nawet o 50-75\%. Redukcja dawki obowiązuje również w przypadku niewydolności nerek. Jeśli klirens kreatyniny $(\mathrm{CrCl}$, creatinine clearence) wynosi poniżej $50 \mathrm{ml} /$ /min, to dawkę należy ograniczyć o $25 \%$, a jeśli $\mathrm{CrCl}$ utrzymuje się poniżej $15 \mathrm{ml} / \mathrm{min}$ — to o $50 \%$ $[33,35]$.

Zastosowanie IVIG w leczeniu HLH jest nie tylko częścią leczenia hamującego nadmierną reakcję zapalną, ale również wspomaga upośledzoną w tej chorobie odporność humoralną. Dożylne immunoglobuliny powinny być stosowane raczej w większych dawkach immunosupresyjnych, tj. 1-2g/ $/ \mathrm{kg}$ mc. przez 2-3 dni. U pacjentów z przemijającymi epizodami HLH indukowanymi infekcją pulsy IVIG w dawce $0,5 \mathrm{~g} / \mathrm{kg}$ mc. $\mathrm{z}$ glikokortykosteroidami stosowane $\mathrm{w}$ leczeniu podtrzymującym często pozwalają na zahamowanie HLH.

$\mathrm{W}$ prezentowanym przypadku nie podawano MTX i.t., ponieważ nie obserwowano cech zajęcia OUN w badaniu klinicznym, w badaniu płynu mózgowo-rdzeniowego ani MRI mózgu. Nie ma danych wskazujących na konieczność podawania MTX i.t. dorosłym pacjentom bez objawów neurologicznych.

Dla wielu chorych jedynym skutecznym postępowaniem leczniczym jest procedura allo-HSCT. Pierwszy opis allo-HSCT $\mathrm{u}$ chorego $z$ HLH pochodzi z 1986 roku [36]. Jest to leczenie $z$ wyboru u pacjentów $z$ rozpoznaniem FLH, u których poprawę po leczeniu konwencjonalnym można uzyskać jedynie na krótki okres, a wrodzony defekt genetyczny determinuje pewność nawrotu i niekorzystne rokowanie. U pacjentów $z$ nabytą postacią HLH procedura allo-HSCT jest wskazana w przypadku braku CR po 8 tygodniach leczenia oraz w przypadku nawrotu HLH. Transplantacja w aktywnej fazie HLH jest przeciwwskazana $z$ powodu bardzo dużego ryzyka powikłań, w tym GvHD oraz braku wszczepienia sięgającego nawet $22 \%$ [28, 37]. U opisywanego chorego allo-HSCT przeprowadzono w okresie trzeciej remisji.

Brakuje ścisłych danych epidemiologicznych wskazujących na odsetek trwałych wyleczeń nabytej postaci HLH z zastosowaniem terapii konwen- cjonalnej, ale szacunkowe dane wskazują, że nie przekracza on 50-60\%. Dlatego jest uzasadnione poszukiwanie potencjalnego dawcy rodzinnego lub niespokrewnionego jak najwcześniej po ustaleniu rozpoznania [38]. W przypadku opisanego chorego poszukiwania wdrożono w okresie nawrotu, ponieważ pierwotna manifestacja HLH nie spełniała wszystkich kryteriów rozpoznania choroby. Potrzebę wczesnego poszukiwania dawcy potwierdza przebieg kliniczny u chorego. Bardzo szybko doszło u niego do kolejnego nawrotu HLH - już bez ewidentnego czynnika sprawczego. Intensyfikacja leczenia umożliwiła bezpieczne przeprowadzenie $\mathrm{u}$ chorego procedury allo-HSCT po uzyskaniu kolejnej remisji. W kondycjonowaniu przed transplantacją u pacjenta zastosowano schemat o zredukowanej intensywności (RIC, reduced-intensity conditioning). Jest to postępowanie zalecane, ponieważ istotnie poprawia długotrwałe OS chorych w porównaniu $z$ kondycjonowaniem mieloablacyjnym, zwiększając je $z$ 43\% do nawet $95 \%$ [39]. Jednak w populacji chorych poddanych RIC istotnymi problemami klinicznymi pozostają utrzymywanie się mieszanego chimeryzmu hematopoetycznego po allo-HSCT i utrata przeszczepu [39]. Dlatego w przypadku omawianego pacjenta klasyczny schemat RIC, złożony $z$ fludarabiny, melfalanu i ATG, uzupełniono o immunosupresyjną dawkę cyklofosfamidu. Mimo to $\mathrm{w}+46$. dobie po allo-HSCT w badaniu chimeryzmu wykazano jedynie $56 \%$ DNA dawcy. W takich przypadkach zaprzestanie leczenia immunosupresyjnego jest jedną $z$ zalecanych metod postępowania, co zastosowano u chorego $z$ korzystnym efektem. Utrata chimeryzmu dawcy to czynnik ryzyka nawrotu HLH po allo-HSCT, co jest opisywane nawet u 8,8\% chorych [40]. Dlatego wczesna interwencja terapeutyczna ma bardzo duże znaczenie. Największe zagrożenie nawrotami HLH obserwuje się u chorych do 100 dni po allo-HSCT, jednak są one obserwowane nawet do 180 dni po przeszczepieniu [41]. W okresie późniejszym ryzyko to staje się marginalne. $\mathrm{W}$ odniesieniu do opisywanego chorego daje to podstawy do stwierdzenia, że zastosowane leczenie wraz $z$ allo-HSCT wiąże się $z$ bardzo dobrym dalszym rokowaniem.

\section{Podsumowanie}

Limfohistiocytoza hemofagocytarna nie jest chorobą częstą, ale najprawdopodobniej zbyt rzadko rozpoznawaną. Jej diagnostyka jest trudna z powodu niskiej swoistości kryteriów klinicznych i laboratoryjnych oraz małej dostępności badań genetycznych (w przypadku podejrzenia pierwotnej 
HLH) oraz testów o wyższej specyficzności, takich jak badanie sCD25 czy ocena aktywności komórek NK. Brak prospektywnych badań klinicznych u dorosłych chorych na HLH powoduje, że nie ma zaleceń dotyczących ich leczenia. Wydaje się, że proste przeniesienie schematów opracowanych dla dzieci może skutkować większą toksycznością leczenia. Zaprezentowany przypadek ilustruje, jakie trudności diagnostyczne występują u chorego na sHLH, wskazuje na skomplikowany i nawrotowy przebieg kliniczny tej choroby oraz na problemy w leczeniu i wygaszaniu nieprawidłowej odpowiedzi immunologicznej, wymagające intensywnego leczenia, w tym procedury allo-HSCT.

Należy podkreślić potrzebę dużej czujności klinicznej i uwzględniania możliwości wystąpienia HLH u chorych z gorączką, organomegalią i pancytopenią, ponieważ opóźnienie w rozpoznaniu i leczeniu w tym przypadku może doprowadzić do nieodwracalnej niewydolności wielonarządowej i/lub zgonu chorego. Niewątpliwie HLH wymaga dalszych badań nad jej patomechanizmem, ulepszenia metod diagnostycznych oraz określenia zaleceń dotyczących leczenia dorosłych chorych.

\section{Piśmiennictwo}

1. Janka G.E. Familial and acquired hemophagocytic lymphohistiocytosis. Annu Rev. Med. 2012; 63: 233-246.

2. Verbsky J.W., Grossman W.J. Hemophagocytic lymphohistiocytosis: diagnosis, pathophysiology, treatment, and future perspectives. Ann. Med. 2006; 38: 20-31.

3. Henter J.I., Elinder G., Söder O., Ost A. Incidence in Sweden and clinical features of familial hemophagocytic lymphohistiocytosis. Acta Paediatr. Scand. 1991; 80: 428-435.

4. Niece JA., Rogers ZR., Ahmad N., Langevin AM., McClain KL. Hemophagocytic lymphohistiocytosis in Texas: observations on ethnicity and race. Pediatr. Blood Cancer 2010; 54: 424-428.

5. Janka G.E. Hemophagocytic lymphohistiocytosis. Hematology 2005; 10 (supl. 1): 104-107.

6. Parkih S.A., Kapoor P., Letendre L., Kumar S., Wolanskyj A.P. Prognostic factors and outcomes of adults with hemophagocytic lymphohistiocytosis. Mayo Clin. Proc. 2014; 89: 484-492.

7. Ramos-Casals M., Brito-Zerón P., López-Guillermo A., Khamashta M.A., Bosch X. Adult haemophagocytic syndrome. Lancet 2014; 383: 1503-1516.

8. Atteritano M., David A., Bagnato G. i wsp. Haemophagocytic syndrome in rheumatic patients. A systematic review. Eur. Rev. Med. Pharmacol. Sci. 2012; 16: 1414-1424.

9. Stabile A., Bertoni B., Ansuini V. i wsp. The clinical spectrum and treatment options of macrophage activation syndrome in the pediatric age. Eur. Rev. Med. Pharmacol. Sci. 2006; 10: 53-59.

10. Janka G., Imashuku S., Elinder G. i wsp. Infection- and malignancy-associated hemophagocytic syndromes: secondary hemophagocytic lymphohistiocytosis. Hematol. Oncol. Clin. North Am. 1998; 12: 435-444.

11. Henter JI., Samuelsson-Horne A., Arico M. i wsp. Treatment of hemophagocytic lymphohistiocytosis with HLH-94 immunoche- motherapy and bone marrow transplantation. Blood 2002; 100: 2367-2373.

12. Arico M., Janka G., Fischer A. i wsp. Hemophagocytic lymphohistiocytosis: report of 122 children from the International Registry. FHL Study Group of the Histiocyte Society. Leukemia 1996; 10: 197-203.

13. Buyse S., Teixeira L., Galicier L. i wsp. Critical care management of patients with hemophagocytic lymphohistiocytosis. Intensive Care Med. 2010; 36: 1695-1702.

14. Rosado F.G., Kim A.S. Hemophagocytic lymphohistiocytosis: an update on diagnosis and pathogenesis. Am. J. Clin. Pathol. 2013; 139: 713-727.

15. Henter J.I., Horne A., Aricó M. i wsp. HLH-2004: diagnostic and therapeutic guidelines for hemophagocytic lymphohistiocytosis. Pediatr. Blood Cancer 2007; 48: 124-131.

16. Lehmberg K., Nichols K.E., Henter J.L. i wsp. Consensus recommendations for the diagnosis and management of hemophagocytic lymphohistiocytosis associated with malignancies. Haematologica 2015; 100: 997-1004.

17. Rouphael N.G., Talati N.J., Vaughan C. i wsp. Infections associated with haemophagocytic syndrome. Lancet Infect. Dis. 2007; 7: 814-822.

18. Rivière S., Galicier L., Coppo P. i wsp. Hemophagocytic syndrome in adults: a retrospective analysis of 162 patients. Am. J. Med. 2014; 127: 1118-1125.

19. Magro C.M., Crowson A.N., Kovatich A.J., Burns F. Lupus profundus, indeterminate lymphocytic lobular panniculitis and subcutaneous T-cell lymphoma: a spectrum of subcuticular T-cell lymphoid dyscrasia. J. Cutan Pathol. 2001; 28: 235-247.

20. Willemze R., Jansen P.M., Cerroni L. i wsp. Subcutaneous panniculitis-like T-cell lymphoma: definition, classification, and prognostic factors: an EORTC Cutaneous Lymphoma Group Study of 83 cases. Blood 2008; 111: 838-845.

21. Bosisio F., Boi S., Caputo V. i wsp. Lobular panniculitic infiltrates with overlapping histopathologic features of lupus panniculitis (lupus profundus) and subcutaneous T-cell lymphoma: a conceptual and practical dilemma. Am. J. Surg. Pathol. 2015; 39: 206-211.

22. George M.R. Hemophagocytic lymphohistiocytosis: review of etiologies and management. J. Blood Med. 2014; 5: 69-86.

23. Allen C.E., Yu X., Kozinetz C.A., McClain K.L. Highly elevated ferritin levels and the diagnosis of hemophagocytic lymphohistiocytosis. Pediatr. Blood Cancer 2008; 50: 1227-1235.

24. Grangé S., Buchonnet G., Besnier E. i wsp. The use of ferritin to identify critically ill patients with secondary hemophagocytic lymphohistiocytosis. Crit. Care Med. 2016; 44: e1045-e1053.

25. Nikiforow S., Berliner N. The unique aspects of presentation and diagnosis of hemophagocytic lymphohistiocytosis in adults. Hematology Am. Soc. Hematol. Educ. Program 2015: 183-189.

26. Gupta A., Weitzman S., Aldelhaleem M. The role of hemophagocytosis in bone marrow aspirates in the diagnosis of hemophagocytic lymphohistiocytosis. Pediatr. Blood Cancer 2008; 50: 192-194.

27. Strauss R., Neureiter D., Westenburger B. i wsp. Multifactorial risk analysis of bone marrow histiocytic hyperplasia with hemophagocytosis in critically ill medical patients - a postmortem clinicopathologic analysis. Crit. Care Med. 2004; 32: 1316-1321.

28. Schram A.M., Berliner N. How I treat hemophagocytic lymphohistiocytosis in the adult patient. Blood 2015; 125: 2908-2914.

29. Fisman D.N. Hemophagocytic syndromes and infection. Emerg. Infect. Dis. 2000; 6: 601-608.

30. Wang S., Degar B.A., Zieske A., Shafi NQ., Rose M.G. Hemophagocytosis exacerbated by G-CSF/GM-CSF treatment in a patient with myelodysplasia. Am. J. Hematol. 2004; 77: 391-396. 
31. Stéphan J.L., Donadieu J., Ledeist F. i wsp. Treatment of familial hemophagocytic lymphohistiocytosis with antithymocyte globulins, steroids, and cyclosporin A. Blood 1993; 82: 2319-2323.

32. Johnson T.S., Terrell C.E., Millen S.H. i wsp. Etoposide selectively ablates activated $\mathrm{T}$ cells to control the immunoregulatory disorder hemophagocytic lymphohistiocytosis. J. Immunol. 2014; 192: 84-91.

33. Imashuku S., Kuriyama K., Teramura T. i wsp. Requirement for etoposide in the treatment of Epstein-Barr virus-associated hemophagocytic lymphohistiocytosis. J. Clin. Oncol. 2001; 19: 2665-2673.

34. Thompson P.A., Allen C.E., Horton T. i wsp. Severe neurologic side effects in patients being treated for hemophagocytic lymphohistiocytosis. Pediatr. Blood Cancer 2009; 52: 621-625.

35. La Rosée P. Treatment of hemophagocytic lymphohistiocytosis in adults. Hematology Am. Soc. Hematol. Educ. Program 2015: 190-196.

36. Fischer A., Cerf-Bensussan N., Blanche S. i wsp. Allogeneic bone marrow transplantation for erythrophagocytic lymphohistiocytosis. J. Pediatr. 1986; 108: 267-270.
37. Ouachee-Chardin M., Elie C., de Saint Basile G. i wsp. Hematopoietic stem cell transplantation in hemophagocytic lymphohistiocytosis: a single-center report on 48 patients. Pediatrics 2006; 117: e734-e750.

38. Jordan M.B., Allen C.E., Weitzman S., Filipovich A.H., McClain K.L. How I treat hemophagocytic lymphohistiocytosis. Blood 2011; 118: 4041-4052.

39. Marsh R.A., Vaughn G., Kim M.O. i wsp. Reduced-intensity conditioning significantly improves survival of patients with hemophagocytic lymphohistiocytosis undergoing allogeneic hematopoietic stem cell transplantation. Blood 2010; 116: 5824-5831.

40. Abdelkefi A., Ben Jamil W., Torjman L. i wsp. Hemophagocytic syndrome after hematopoietic stem cell transplantation: a prospective observational study. Int. J. Hematol. 2009; 98: 368-373.

41. Jordan M.B., Filipovich A.H. Hematopoietic cell transplantation for lymphohistiocytosis: a journey of a thousand miles with a single (big) step. Bone Marrow Transplant. 2008; 42: 433$-437$. 